\title{
Nontarget testing of microbial pest control agents using larvae of the coot clam Mulinia lateralis
}

\author{
Nia M. Gormly ${ }^{1}$, Samuel Singer ${ }^{1}$, Fred J. Genthner ${ }^{2, *}$ \\ ${ }^{1}$ Department of Biological Sciences, Western Illinois University, Macomb, Illinois 61455, USA \\ ${ }^{2}$ U.S. Environmental Protection Agency, National Health and Environmental Effects Research Laboratory, \\ Gulf Ecology Division, Gulf Breeze, Florida 32561, USA
}

\begin{abstract}
A short-term $(48 \mathrm{~h})$ chemical toxicity test using larvae of the coot clam Mulinia lateralis was modified to evaluate potential toxicity and pathogenicity of microbial pest control agents. $M$. lateralis larvae, at the straight-hinged stage of development, were exposed to various microbial pest control agents uncluding: a mosquito larvacide. Bacillus thuringiensis var. israelensis (Bti); a molluscicidal strain of Bacillus alvei; a viral pathogen of the gypsy moth Lymantria dispar nuclear polyhedrosis virus (LdNPV); and a broad host-range fungal insect pathogen, Metarhizium anisopliae. Mortalities significantly higher than heat-killed controls were obtained with Bti at a $10^{-4}$ dilution of a commercial preparation, and with LdNPV at an occlusion body density of $1 \times 10^{f} \mathrm{ml}^{-1}$ Sodium dodecyl sulfate (SDS) and the water-soluble fraction of No. 2 fuel oil (WSF oil $_{\text {il }}$ were also :ested to provide a measure of comparison, sensitivity and precision. SDS, toxic at an $\mathrm{LC}_{50}$ of $6.3 \mathrm{mg} \mathrm{l}^{-1}$, had a mean coefficient of variation of $23 \%$. The clam larval toxicity test was very sensitive to $\mathrm{WSF}_{\text {all }}$ exposures resulted in an $\mathrm{LC}_{50}$ of $<10 \% \mathrm{v} / \mathrm{v}$. Because of its precision, sensitivity and simplicity, the $M$. lateralis larval test has the potential to be useful for assessing adverse effects that microbial pest ccntrol agents may have on nontarget bivalves.
\end{abstract}

KEY WORDS: Biological control Nontarget effects $\cdot$ Mulinia lateralis

\section{INTRODUCTION}

Microbial pest control agents (MPCAs) are receiving renewed attention from private industry for potential commercialization, particularly in cases where the pest is not effectively controlled by chemical pesticides (Osborne \& Landa 1992) or where the use of chemical pesticides poses a significant risk to either human health or the environment. These factors, plus public sentiment which favors limiting the use of chemical pesticides, have created a promising market for such biological products. As a result, the majority of MPCA registrations have been issued within the last $5 \mathrm{yr}$ (Office of Pesticide Programs, Biopesticide Division, U.S. Environmental Protection Agency).

Because MPCAs must be shown to have high levels of safety to nontarget organisms and ecosystems before being widely used, considerable interest has

- Addressee for correspondence

E-mail: genther.fred@epamail.epa.gov focused on the development of test systems, toxicity tests and pathogenicity tests (Anderson \& Harvey 1992). Although the number of terrestrial applications of MPCAs may well exceed the number of aquatic applications, the diversity and quantity of MPCAs directly or indirectly entering the inland and nearcoastal waters could become considerable. MPCAs may enter the aquatic environment indirectly through runoff or over-spray, or directly to control pests such as mosquitos (Chapman 1985), aquatic weeds (Charudattan et al. 1990), and perhaps in the future, mollusks (Singer et al. 1994). For example, molluscicidal Bacillus sp. are currently being investigated as potential biocontrol agents (Singer et al. 1988, 1994). Therefore, our objective was to develop a mollusc toxicity and pathogenicity test to assess potential nontarget effects of these Bacillus sp. and other MPCAs.

Morrison \& Petrocelli (1991) adapted existing bivalve embryo/larval tests (APHA 1975, ASTM 1989) to an ecologically important mollusc, the coot clam Mulinia lateralis (Calabrese 1970). We chose this 
mactrid bivalve as our test organism because of its small size ( $<2 \mathrm{~cm}$ shell length), broad geographical distribution and ease of culture

In this study we report on the development of an acute, bivalve larvae toxicity and pathogenicity test to assess adverse effects of MPCAs on nontarget aquatic animals. We chose a fungal (Metarhizium anisopliae), a viral (gypsy moth baculovirus), and 2 bacterial (Bacillus thuringiensis var. israelensis, $B$ alvei III3DTiA) MPCAs to adapt this existing bivalve toxicity test for use with microbes. Sodium dodecyl sulfate (SDS), used in the initial development of our toxicity test, provided a reference for standardization and comparison. The water-soluble fraction of No. 2 fuel oil $\left(\mathrm{WSF}_{\text {oil }}\right)$ was also tested to gain an additional measure of test sensitivity.

\section{MATERIALS AND METHODS}

Test animal and maintenance conditions. All seawater, except where noted, was filtered (1 $\mu \mathrm{m})$ and passed through a lifeguard QL-40 Ultraviolet Water Sterilizer (Model M-3, Florida Aqua Farms, Dade City FL, USA). Water temperature was maintained at 22 to $25^{\circ} \mathrm{C}$ while salinity ranged between 24 and $28 \%$.

Mulina lateralis was obtained from Dr George Morrison, NEERL, Atlantic Coast Division, U.S. EPA, Narragansett, RI, USA. Adult clams were maintained in 5 I glass aquaria either equipped with a flow-through seawater $(20 \%, 20 \mu \mathrm{m}$ filtered) delivery system or held static. Approximately $3 \mathrm{~cm}$ of fine beach sand covered the bottom of each aquarium. Clams were fed a marine algae, Isochrysis galbana, daily at a density of $5 \times$ $10^{5}$ cells $\mathrm{ml}^{-1}$. I. galbana was cultured using a commercial algal culture medium (Fritz F/2 Culture Medium; Fritz Chemical Co., Dallas, TX, USA). In static culture one-third of the volume of water was replaced daily as a consequence of feeding

Spawning. Adult clams were cleaned of algae with a soft bristle brush and separated by sex into $200 \mathrm{ml}$ glass bowls containing $100 \mathrm{ml}$ of seawater $(0.22 \mu \mathrm{m}$ filtered). Between 1 and 3 individuals were added to each bowl. To induce spawning, warm seawater was added to the bowls until the temperature reached $28^{\circ} \mathrm{C}$. If spawning did not occur within $40 \mathrm{~min}$, the water temperature was lowered to between 18 and $20^{\circ} \mathrm{C}$ and then again increased to $28^{\circ} \mathrm{C}$. If heat failed to induce spawning, sperm was added to bowls containing females while mature female gonadal tissue was added to bowls containing males

Upon release, the eggs were passed through a $100 \mu \mathrm{m}$ nylon sieve to remove debris. The sperm suspension (1 ml) was added to the eggs. After $1 \mathrm{~h}$, fertilization was confirmed by observing cell division within the embryos. Developing embryos were collected on a $10 \mu \mathrm{m}$ nylon sieve, rinsed 3 times to remove sperm, and placed in a 51 Pyrex bowl containing 2.51 of seawater (0.22 $\mu \mathrm{m}$ filtered).

Clam larval toxicity and pathogenicity test. Larvae, $48 \mathrm{~h}$ after fertilization, were collected on a $35 \mu \mathrm{m}$ nylon sieve, rinsed 3 times, and placed in a 51 Pyrex $^{\circledR}$ bowl containing 2.5 l of seawater ( $0.22 \mu \mathrm{m}$ filtered) at a density of 30 larvae $\mathrm{ml}^{-1}$. Isochrysis galbana was then added at a density of approximately $1 \times 10^{5}$ cells $\mathrm{ml}^{-1}$. This suspension was slowly stirred, while $0.5 \mathrm{ml}$ aliquots containing approximately 15 to 25 clam larvae were distributed into $3 \mathrm{ml}$ wells of a 24 -well microtiter plate (Falcon 3047, Becton Dickinson \& Company, Lincoln Park, NJ, USA).

Tesi materiais isoluitions, suspensions or seawater controls) were immediately added to duplicate microtiter wells in 0.2 or $0.3 \mathrm{ml}$ volumes. Microtiter plates were incubated at $25^{\circ} \mathrm{C}$ under a photoperiod of $12 \mathrm{~h}$ light and $12 \mathrm{~h}$ darkness. The test was scored $48 \mathrm{~h}$ after addition of test material. Using a Zeiss Axiovert model 35 inverted microscope equipped for photomicrography, the number of living larvae, determined by observing beating of the ciliary crest and respiratory circulation, was counted. Death was noted by loss of circulation and ciliary motion, disfiguration, and eventually decomposition. The $\mathrm{pH}$ and dissolved oxygen (DO) in each well were measured at the end of the test.

The trimmed Spearman-Karber method (Hamilton et al. 1978) was used to calculate $L_{50}$ values and confidence limits for the exposures. A 1-way analysis of variance (SAS Institute Inc. 1985) was performed. Tukey's HSD was used to determine whether death was significant among all treatment groups. In tables, letters $\mathrm{A}, \mathrm{B}$, and $\mathrm{C}$ were used to designated treatment groups that were statistically similar. Dunnetts test was used to compare treatments against their respective 'heat-killed' control.

Preparation of chemical toxicants. A stock solution of SDS prepared in seawater at a concentration of $200 \mu \mathrm{g} \mathrm{ml}^{-1}$ was diluted to final concentrations of 0.2 , 2.0 and $20 \mathrm{\mu g} \mathrm{m}^{-1}$ for the clam larval toxicity test. WSF $_{\text {oll }}$ (R.T. Corporation, Laramie, WY, USA) was prepared in seawater according to the methods of Anderson et al. (1974) and either used immediately or stored at $4^{\circ} \mathrm{C}$ for less than $1 \mathrm{wk}$. The toxicity of $\mathrm{WSF}_{\text {oul }}$ to clam larvae was tested at 10,20 and $30 \%(\mathrm{v} / \mathrm{v})$ of full strength

Microbial pest control agents and growth conditions. A spore suspension of Bacillus thuringiensis serovar israelensis (Bti, Vectobac 12AS, ABG 6193) was obtained from Abbott Laboratories, N. Chicago, IL, USA. Bti was also isolated from this commercial preparation and spores prepared by growth in NYSM broth (Myers \& Yousten 1978). Spores produced in our 
laboratory were suspended in seawater to the same density as the commercial preparation. Both Bti suspensions were stored at $4^{\circ} \mathrm{C}$ until use. Bacillus alvei III3DTiA was cultured, and a final whole culture (powder) was prepared as described by Singer et al. (1994). The powder was stored at $25^{\circ} \mathrm{C}$ in a desiccator and diluted in seawater before testing. Occlusion bodies of gypsy moth Lymantria dispar nuclear polyhedrosis virus (LdNPV) were obtained from J.P. Burand, Dept of Entomology, University of Massachusetts, Amherst, MA, USA, and stored at $4^{\circ} \mathrm{C}$. All of the previously mentioned MPCAs were tested by the clam larval toxicity and pathogenicity test as $10^{-4}, 10^{-5}$, and $10^{-6}$ dilutions of the concentrated stock suspensions or final whole culture.

Metarhizium anisopliae 1080 was obtained from the USDA-ARS collection of entomopathogenic fungal cultures (Ithaca, NY, USA) and cultured at $25^{\circ} \mathrm{C}$. Conidiospore densities were determined using a hemocytometer. Viable and direct spore counts were performed as described by Genthner \& Middaugh (1995). Conidiospores of $M$. anisopliae were produced by adding approximately $1 \times 10^{4}$ spores to $0.3 \mathrm{ml}$ of a sterile caterpillar homogenate (corn earworm Helicoverpa $z e a)$. This suspension was spread onto the surface of $\mathrm{MM}$ agar plates which contained (per liter): $\mathrm{KH}_{2} \mathrm{PO}_{4}$, $1 \mathrm{~g} ; \mathrm{MgSO}_{4}, 0.5 \mathrm{~g}_{i}$ and agar, $15 \mathrm{~g}$. The $\mathrm{pH}$ of the medium was adjusted to 6.0 before sterilization in an autoclave. After 6 to $8 \mathrm{~d}$, conidiospores produced on MM agar plates were harvested by scraping the confluent mycelial mats with a sterile spatula. Conidia were suspended in sterile sea water by gentle aspiration in a hand-held tissue homogenizer at a density of approximately $1 \times 10^{8}$ spores $\mathrm{ml}^{-1}$. This concentrated stock was used for larval exposures within $4 \mathrm{~h}$ of preparation. $M$. anisopliae was tested by the clam larval toxicity and pathogenicity test at conidiospore densities of $10^{6}, 10^{5}$, and $10^{4} \mathrm{ml}^{-1}$.

Heat-killed controls of all MPCAs were prepared by sterilizing a concentrated stock suspension in an autoclave ( $20 \mathrm{~min}, 15 \mathrm{lb} / \mathrm{in}^{2}=2 \mathrm{bar}$ ). All heat-killed controls were tested at the high concentration or density.

Tests of MPCAs for potency assessment against their respective target organisms. To assure that the MPCA preparations used in the clam larval toxicity and pathogenicity test possessed activity against a target organism, the following tests were performed. The potency of Bti was determined by a toxicity test against 3rd instar Aedes aegypti as described by McLaughlin et al. (1984). The molluscicidal toxicity of Bacillus alvei III3DTiA was determined using the snail Biomphalaria glabrata (Singer et al. 1994). A neonate pathogenicity test using gypsy moth larvae was used to determine LdNPV virulence (Burand \& Park 1992). Lastly, a corn earworm (Helicoverpa zea) pathogenicity test was per- formed on the Metarhizum anisopliae conidiospore preparations. H. zea, obtained as eggs from the USDAARS Laboratory in Tifton, GA, USA, were reared to 3rd instar at $25^{\circ} \mathrm{C}$ on a diet consisting of ground raw pinto beans, $14 \mathrm{~g}$; wheat germ, $10 \mathrm{~g}$; torula yeast, $6.3 \mathrm{~g}$; casein, $5.0 \mathrm{~g}$; methyl-paraben, $0.4 \mathrm{~g}$; sorbic acid, $0.2 \mathrm{~g}$; agar, $2.3 \mathrm{~g}$; and distilled water, $135 \mathrm{ml}$. Caterpillars were immersed for $1 \mathrm{~min}$ in suspensions of conidiospores at densities of $1 \times 10^{4-8} \mathrm{ml}^{-1}$. The control was a sterile distilled water immersion. Because the diet contained fungal inhibitors, caterpillars were held for $24 \mathrm{~h}$ in individual insect-rearing cups without food to allow for spore germination and outgrowth on the insect cuticle. Fungal death, determined by observing for fungal growth on the cadaver with the aid of a dissecting microscope, was scored after $5 \mathrm{~d}$. A total of 20 caterpillars were exposed per treatment. $\mathrm{LC}_{50}$ values and confidence limits were calculated from 5 replicates of each treatment.

\section{RESULTS}

At the end of the clam larvae test ( $48 \mathrm{~h}$ ), normal, healthy, straight-hinged larvae appeared as in Fig. $1 \mathrm{~A}$. Mortality was scored as the absence of ciliary action and lack of circulation observable through the semitransparent shell. Death was accompanied by shell gaping with destruction of the tissue as shown in Fig. 1B. During the development of the clam larvae
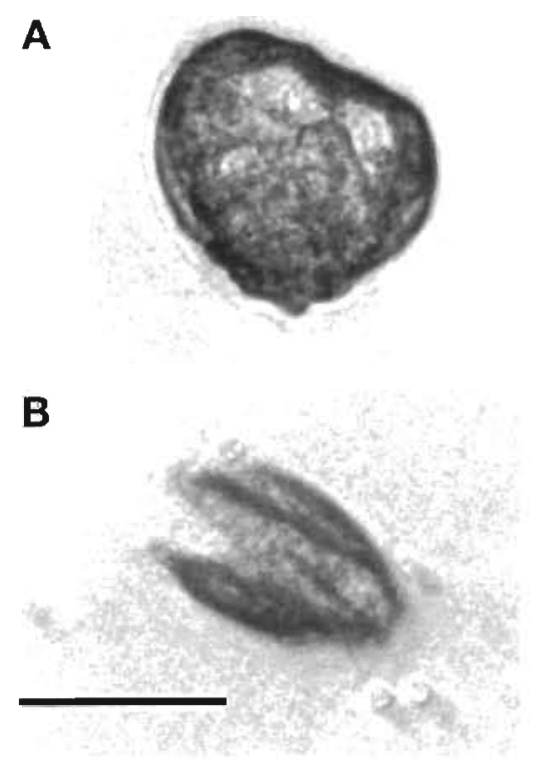

Fig. 1. Mulinia lateralis. (A) Straight-hinged larva. (B) Dead larva showing gaping and disintegration of tissue. Scale bar $=50 \mu \mathrm{m}$ for $\mathrm{A}$ and $\mathrm{B}$ 
test, longer exposure times were tested. However, if tests were allowed to run longer than $48 \mathrm{~h}$, control mortalities would often exceed acceptable levels. Thus, our clam larvae test was limited to a $48 \mathrm{~h}$ exposure.

Toxicity of SDS and WSF $_{\text {oil }}$ to Mulinia lateralis larvae is shown in Table 1. Triplicate exposures of 20 larvae to each of 3 concentrations of SDS resulted in an $\mathrm{LC}_{50}$ (95\% CL) of 6.3 (3.8 to 10.6$) \mathrm{mg}^{-1}$ and a coefficient of variation $(\mathrm{CV})$ of $23 \%$. The $\mathrm{LC}_{50}$ value for $\mathrm{WSF}_{\text {oil }}$ was $<10 \%$ because, even at the most dilute concentration tested $\left(10 \% \mathrm{WSF}_{\mathrm{oil}}\right), 95 \%$ mortality was obtained.

Activities of all microbial pest control agents were determined to assure potency of the preparations towards their respective target organisms (Table 2).

Table 3 presents results of the MPCAs tested by the clam larval toxicity and pathogenicity assay. The commercial preparation of Bti showed significant mortality toward clam larvae at the highest concentration tested, a $1 \times 10^{-4}$ dilution of the product. This significance was obtained from a comparison against a heat-killed control at the same concentration. The Bti preparation

Table 1. Mulinia lateralis. Survival of coot clam larvae exposed to chemical toxicants in a static, acute $48 \mathrm{~h}$ test

\begin{tabular}{|lccc|}
\hline Chemical & Treatment & \% Mortality & LC $_{50}(95 \% \mathrm{CL})$ \\
\hline Sodium dodecyl sulfate & & & $6.3(3.8-10.6) \mathrm{mg} \mathrm{l}^{-1} \mathrm{a}$ \\
& Control & 20 & \\
& $0.2 \mathrm{mg} \mathrm{l}^{-1}$ & 25 & \\
$2.0 \mathrm{mg} \mathrm{l}^{-1}$ & 45 & \\
$20 \mathrm{mg} \mathrm{l}^{-1}$ & 75 & $<10 \% \mathrm{v} / \mathrm{v}$ \\
No. 2 fuel oil (water-soluble fraction) & & \\
Control & 12 & \\
$10 \% \mathrm{v} / \mathrm{v}$ & 95 & \\
$20 \% \mathrm{v} / \mathrm{v}$ & 100 & \\
$30 \% \mathrm{v} / \mathrm{v}$ & 100 & \\
& & \\
a Mean of triplicate determinations & \\
\hline
\end{tabular}

cultured in our laboratory did not, however, show significant mortalities when compared against the heat-killed control. With both preparations a definitive dose-response trend based on concentration was obtained resulting in significant mortality differences between the low and high concentrations. Our laboratory-cultured Bti preparation contained $3 \times 10^{7}$ viable spores $\mathrm{ml}^{-1}$, while the commercial Bti preparation contained $1.1 \times 10^{7}$ viable spores $\mathrm{ml}^{-1}$. The commercial preparation showed a slightly higher toxicity toward mosquito larvae, with an $\mathrm{LC}_{50}$ of $3.4 \times 10^{-8}$, compared with the laboratory cultured Bti preparation which had an $L_{50}$ value toward mosquito larvae of $2 \times 10^{-8}$ (Table 2).

Both the killed-control and the high concentration of Bacillus alvei III3DTiA caused high mortalities $(\geq 95 \%)$ in the clam larval toxicity and pathogenicity test (Table 3). These high mortalities were accompanied by very low DO concentrations $(42 \%$ saturation) in the test wells. At the lowest concentration of $B$. alvei III3DTiA tested, survival of clam larvae was $95 \%$. Metarhizium anisopliae did not cause high clam larvae mortalities with the heat-killed control nor with any of the viable spore treatments (Table 4). Thus, no significant differences between the viable spore treatments and the heatkilled control were obtained.

At the highest density of gypsy moth virus tested with the clam larval toxicity and pathogenicity test, significantly higher mortalities were obtained when compared with the heat-killed control. No mortalities were observed in the heatkilled control, while clam larval survival at the high density of LdNPV occlusion bodies was $81 \%$ (Table 4 ).

Table 2. Activity of microbial pest control agents towards their respective target organisms

\begin{tabular}{|c|c|c|}
\hline Microbial pest control agent & Target pest & Activity \\
\hline $\begin{array}{l}\text { Bacillus thuringiensis var. } \\
\text { israelensis (Vectobac }{ }^{(1)} \text { ) }\end{array}$ & $\begin{array}{l}\text { Mosquito larvae (Aedes } \\
\text { aegypti, 3rd instar) }\end{array}$ & $\mathrm{LC}_{50}(95 \% \mathrm{CL})^{\alpha}=3.4 \times 10^{-8}(2.6-4.5)$ \\
\hline $\begin{array}{l}\text { Bacillus thuringiensis var. } \\
\text { israelensis (Iaboratory culture) }\end{array}$ & $\begin{array}{l}\text { Mosquito larvae (Aedes } \\
\text { aegypti, 3rd instar) }\end{array}$ & $\begin{array}{l}\mathrm{LC}_{50}(95 \% \mathrm{CL})^{\mathrm{b}}=2 \times 10^{-8} \\
\text { (not reliable) }\end{array}$ \\
\hline Bacillus alvei III3DTiA & Snail (Biomphalaria glabrata, 3-5 mm) & $\mathrm{LC}_{50}=4 \times 10^{-4}$ dilution of culture \\
\hline Baculovirus & Gypsy moth (Lymantria dispar, neonate) & $\begin{array}{l}L^{L} D_{50}(95 \% C L)=4.8(2.6-8.5) \text { occlusion } \\
\text { bodies per insect, at } 20 \mathrm{~d} \text { post-infection }\end{array}$ \\
\hline Metarhizium anisopliae 1080 & Corn earworm (Helicoverpa zea, 3rd instar) & $\begin{array}{l}\mathrm{LD}_{50}(95 \% \mathrm{CL})^{\mathrm{c}}=1.1 \times 10^{5} \\
(0.46-2.6) \text { spores per ml }\end{array}$ \\
\hline \multicolumn{3}{|c|}{$\begin{array}{l}{ }^{2} \mathrm{LC}_{50} \text { is expressed as the dilution of the commercial product, Vectobac } \mathrm{c}^{\mathrm{B}} \text {, which killed } 50 \% \text { of } \mathrm{A} \text {. aegypti larvae } \\
{ }^{\mathrm{b}} \mathrm{LC}_{50} \text { is expressed as the dilution of the laboratory culture which killed } 50 \% \text { of A. aegypti larvae } \\
{ }^{c} \text { Third-instar H. zea were exposed to suspensions of conidiospores at different densities }\end{array}$} \\
\hline
\end{tabular}


Table 3. Mulina lateralis. Responses of larvae to bacterial pest control agents

\begin{tabular}{|c|c|c|c|c|c|}
\hline Microbial pest control agent & Treatment & $\begin{array}{l}\text { Dilution of product } \\
\text { or culture }\end{array}$ & $\begin{array}{c}\% \text { Survival } \\
\text { at } 48 \mathrm{~h}\end{array}$ & $\begin{array}{l}\text { ANOVA and } \\
\text { Dunnetts test }\end{array}$ & $\begin{array}{l}\text { ANOVA and } \\
\text { Tukey grouping }\end{array}$ \\
\hline $\begin{array}{l}\text { Bacillus thuringiensis serovar } \\
\text { israelensis, Vectobac }\end{array}$ & $\begin{array}{l}\text { Killed-control } \\
\text { Low } \\
\text { Medium } \\
\text { High }\end{array}$ & $\begin{array}{l}1 \times 10^{-4} \\
1 \times 10^{-6} \\
1 \times 10^{-5} \\
1 \times 10^{-4}\end{array}$ & $\begin{array}{l}90 \\
97 \\
84 \\
57\end{array}$ & $\begin{array}{c}- \\
\text { ns } \\
\text { ns } \\
\mathrm{p}<0.05\end{array}$ & $\begin{array}{c}A \\
A \\
A, B \\
B\end{array}$ \\
\hline $\begin{array}{l}\text { Bacillus thuringiensis serovar } \\
\text { israelensis, cultured } \\
\text { for this study }\end{array}$ & $\begin{array}{l}\text { Killed-control } \\
\text { Low } \\
\text { Medium } \\
\text { High }\end{array}$ & $\begin{array}{l}1 \times 10^{-4} \\
1 \times 10^{-6} \\
1 \times 10^{-5} \\
1 \times 10^{-4}\end{array}$ & $\begin{array}{l}72 \\
87 \\
67 \\
57\end{array}$ & $\begin{array}{l}- \\
\text { ns } \\
\text { ns } \\
\text { ns }\end{array}$ & $\begin{array}{c}A, B \\
A \\
A, B \\
B\end{array}$ \\
\hline Bacillus alvei III3DTiA & $\begin{array}{l}\text { Killed-control } \\
\text { Low } \\
\text { Medium } \\
\text { High }\end{array}$ & $\begin{array}{l}1 \times 10^{-4} \\
1 \times 10^{-6} \\
1 \times 10^{-5} \\
1 \times 10^{-4}\end{array}$ & $\begin{array}{r}5 \\
95 \\
58 \\
0\end{array}$ & $\begin{array}{l}\quad- \\
p<0.05 \\
p<0.05 \\
\quad \text { ns }\end{array}$ & $\begin{array}{l}\text { A } \\
\text { C } \\
B \\
\text { A }\end{array}$ \\
\hline
\end{tabular}

Table 4. Mulina lateralis. Responses of larvae to fungal and viral pest control agents

\begin{tabular}{|c|c|c|c|c|c|}
\hline Microbial pest control agent & Treatment & $\begin{array}{c}\text { Density (spores or } \\
\text { occlusion bodies per ml) }\end{array}$ & $\begin{array}{c}\% \text { Survival } \\
\text { at } 48 \mathrm{~h}\end{array}$ & $\begin{array}{l}\text { ANOVA and } \\
\text { Dunnetts test }\end{array}$ & $\begin{array}{l}\text { ANOVA and } \\
\text { Tukey grouping }\end{array}$ \\
\hline Metarhizium anisopliae & $\begin{array}{c}\text { Killed-control } \\
\text { Low } \\
\text { Medium } \\
\text { High }\end{array}$ & $\begin{array}{l}1 \times 10^{6} \\
1 \times 10^{4} \\
1 \times 10^{5} \\
1 \times 10^{6}\end{array}$ & $\begin{array}{l}81 \\
91 \\
96 \\
93\end{array}$ & $\begin{array}{l}- \\
\text { ns } \\
\text { ns } \\
\text { ns }\end{array}$ & $\begin{array}{l}A \\
A \\
A \\
A\end{array}$ \\
\hline $\begin{array}{l}\text { Gypsy moth, Lymantria dispar, } \\
\text { nuclear polyhedrosis virus }\end{array}$ & $\begin{array}{c}\text { Killed-control } \\
\text { Low } \\
\text { Medium } \\
\text { High }\end{array}$ & $\begin{array}{l}1 \times 10^{6} \\
1 \times 10^{4} \\
1 \times 10^{5} \\
1 \times 10^{6}\end{array}$ & $\begin{array}{r}100 \\
98 \\
97 \\
81\end{array}$ & $\begin{array}{c}- \\
\text { ns } \\
\text { ns } \\
p<0.05\end{array}$ & $\begin{array}{c}\text { A } \\
\text { A } \\
A, B \\
B\end{array}$ \\
\hline
\end{tabular}

\section{DISCUSSION}

The short-term larval toxicity test using the coot clam Mulinia lateralis was readily adaptable for use with MPCAs. The test was easy to perform and required small sample volumes. Because of the coot clam's ease of culture, small size, and ability to thrive in a wide range of salinities ( 7 to $32 \%$ ), it has been chosen by several researchers for toxicity studies (Calabrese \& Rhodes 1974, Ho \& Zubkoff 1982, Burgess \& Morrison 1994). Although Morrison \& Petrocelli (1991) reported that laboratory cultures of $M$. lateralis can be maintained in spawning conditions year-round, we found that between May and August spawning was most easily induced and viable eggs were readily obtainable. From September through April clams were either in an inactive stage or in early gametogenesis and would spawn only if they were well conditioned.

Morrison \& Petrocelli (1991) determined the toxicity of SDS using a static, short-term (48 h) Mulinia lateralis larvae test at salinities of 10 and $30 \%$. At a salinity of $10 \%$ these investigators reported an $\mathrm{EC}_{50}$ value of
$8.2 \mathrm{mg} \mathrm{l}^{-1}$ with a CV of $18.3 \%$, and at a salinity of $30 \%$, an $\mathrm{EC}_{50}$ value of $5.8 \mathrm{mg} \mathrm{l}^{-1}$ was obtained with a CV of $55.2 \%$. We report an $\mathrm{LC}_{50}(95 \% \mathrm{CL})$ value of 6.3 (3.8 to 10.6) $\mathrm{mg} \mathrm{l}^{-1}$ with a corresponding $\mathrm{CV}$ of $23 \%$ using a salinity of between 24 and $28 \mathrm{ppt}$ (Table 1). Thus, the sensitivity and precision of our test, reported as a 'lethal concentration, LC', was comparable to the results obtained by Morrison \& Petrocelli (1991), where sublethal endpoints were included in the analysis with results reported as 'effective concentration, EC'.

In measuring the toxicity of WSF $_{\text {oil }}$ the sensitivity of our short-term, static Mulinia lateralis larval test appears to be greater than the developing shrimp embryo test of Fisher \& Foss (1993). In a study which compared toxicity test methods using embryos of the grass shrimp Palaemonetes pugio Rayburn et al. (1995) reported that the $12 \mathrm{~d} \mathrm{LC}_{50}$ in 24 -well plastic plates was $12.7 \%$ $\mathrm{v} / \mathrm{v} \mathrm{WSF}_{\text {oil }}$. In our study, also performed in 24-well plastic plates, a $2 \mathrm{~d} \mathrm{LC}_{50}$ value for $\mathrm{WSF}_{\mathrm{ou}}$ was $<10 \%$ $\mathrm{v} / \mathrm{v}$.

All MPCA preparations showed activity toward their target organisms (Table 2). When testing MPCAs, we 
believe that control toxicity and pathogenicity tests are necessary to verify the activity or virulence of each preparation. Indeed, Nestrud \& Anderson (1994), investigating aquatic safety of Lagenidium giganteum on fish and invertebrates, recommended that sensitive target animals for the MPCA be evaluated by concurrent exposure with the nontarget organism.

The highest concentration of the Bti commercial preparation showed significant mortality toward clam larvae when compared against the heat-killed control. Significant mortality was not obtained, however, with the laboratory-cultured Bti preparation. The high (72\%) heat-killed control mortality in the laboratory-cultured Bti preparation negated a significant difference in mortalities between the high concentration of the laboratory-cultured Bti preparation and the heat-killed control. Nevertheless, the fact that $57 \%$ of clam larvae died after exposure to the high concentrations of both the commercial- and laboratory-cultured preparations of Bti suggests that at very high concentrations Bti may adversely affect this nontarget aquatic species.

High mortalities of clam larvae were obtained upon exposure to Bacillus alvei III3DTiA in the medium, high, and heat-killed control treatments. These mortalities were due to the composition of the $B$. alvei III3DTiA preparation, which contained a large proportion of dried culture media. We believe that the culture medium stimulated growth of bacteria naturally found in the test water, which lowered the DO below 5 ppm and killed the clam larvae. Because of these difficulties any toxicity that the preparation may have had toward the clam larvae would have been overshadowed by the effect of the low DO.

Significant mortalities were not observed with exposures of clam larvae to conidiospores of Metarhizium anisopliae. A longer exposure would have been more desirable for assessing nontarget effects of this pathogen. The effects that this fungus had on fish and shrimp embryos did not manifest themselves until $4 \mathrm{~d}$ of exposure (Genthner \& Middaugh 1995, Genthner et al. 1995)

At the high density of occlusion bodies $\left(1 \times 10^{6} \mathrm{ml}^{-1}\right)$, LdNPV demonstrated significant mortalities compared with the heat-killed control. Because LdNPV normally require several days to infect and kill gypsy moth larvae, it is unlikely that a viral infection caused the mortalities in the clam larvae. A comparison of zero deaths in the 'heat-killed' control against $81 \%$ mortality in the high occlusion body density produced the significant ( $p<0.05)$ response. Perhaps, the heat treatment rendered the occlusion bodies less harmful to the clam larvae.

The Mulinia lateralis larval toxicity and pathogenicity test is easy to perform, requires small sample volumes, has comparable precision and sensitivities to other similar tests (Morrison \& Petrocelli 1991, Rayburn et al. 1995) and was readily adaptable for testing MPCAs. Disadvantages of this test are that at certain times of the year, September through April, clams would spawn only if well conditioned, and the short duration of this test may not allow enough time for pathogens to infect and kill. Our results, however, do provide a useful test method for assessing effects of MPCAs on nontarget bivalves. Lastly, our results and the results of Nestrud \& Anderson (1994) underscore the need to verify the potency of the test agent toward the target organism when performing risk evaluations of MPCAs.

Acknowledgements. We acknowledge Dr Jimmy Bechnel for assistance with the Aedes aegypti toxicity tests, Drs John Burand and En Ju Park for providing LdNPV and performing the gypsy moth pathogenicity tests, Ms Heidi Kumpf for performing the corn earworm pathogenicity tests, Mr Michael Hemmer for assistance with statistical analyses, Dr James Rayburn for helpful discussions, and Mr Larry Goodman for assistance in culturing the coot clam. Mention of tradenames or commercial products does not imply endorsement by the U.S. Environmental Protection Agency. Contribution No. 939 , NHEERL, Gulf Ecology Division, U.S. EPA, Gulf Breeze, FL, USA

\section{LITERATURE CITED}

Anderson JW, Neff JM, Cox BA, Tatem HE, Hightower GM (1974) Characteristics of dispersion and water-soluble extracts of crude and refined oils and their toxicity to estuarine crustaceans and fish. Mar Biol 27:75-88

Anderson R, Harvey $J$ (1992) Procedures and concepts for evaluating effects of microbial pest control agents: a research coordination workshop. ERL-DUL-2686, Duluth, MN. US EPA Office of Research and Development Report

APHA (1975) Bioassay procedures for molluses, 14th edn. American Public Health Association, American Water Works Association and Water Pollution Control Federation, Standard Methods for the Examination of Water and Wastewater. Washington, DC, p 834-845

ASTM (1989) Standard guide for conducting acute toxicity tests starting with embryos of four species of saltwater bivalve molluscs. Annual book of ASTM standards. 11.04. American Society for Testing of Materials, Philadelphia, PA, p 310-327

Burand JP, Park EJ (1992) Effect of nuclear polyhedrosis virus replication on development and pupation of gypsy moth larvae. J Invertebr Pathol 60:171-175

Burgess RM, Morrison GE (1994) A short-exposure, sublethal, sediment toxicity test using the marine bivalve Mulinia lateralis: statistical design and comparative sensitivity. Environ Toxicol Chem 13:571-580

Calabrese A (1.970) The pH tolerance of embryos and larvae of the coot clam, Mulinia lateralis. Veliger 13:122-126

Calabrese A, Rhodes EW (1974) Culture of Mulinia lateralis and Crepidula fornicata embryos and larvae for studies of pollution effects. Thalassia Jugosl 10:89-101

Chapman HC (1985) Biological control of mosquitoes. American Mosquito Control Assocjation, AMAC Bulletın No. 6, Fresno, CA 
Charudattan R, DeValerio JT, Prange VJ (1990) Special problems with aquatic weed control. In: Baker RR, Dunn PE (eds) New directions in biological control: alternatives for suppressing agricultural pests and diseases. Alan R Liss, New York, p 287-303

Fisher WS, Foss SS (1993) A simple test for toxicity of number 2 fuel oil and oil dispersants to embryos of grass shrimp. Palaemonetes pugio. Mar Pollut Bull 26:385-391

Genthner FJ, Middaugh DP (1995) Nontarget testing of an insect control fungus: effects of Metarhizium anisopliae on developing embryos of the inland silverside fish Menidia beryllina. Dis Aquat Org 22:163-171

Genthner FJ, Middaugh DP, Foss SS (1995) Validation of embryo tests for determining effects of fungal pest control agents on nontarget animals. Arch Environ Contam Toxicol 29:540-544

Hamilton MA, Russo RC, Thurston RV (1978) Trimmed Spearman-Karber method for estimating median lethal concentrations in toxicity bioassays. Environ Sci Technol 12:417

Ho MS, Zubkoff PL (1982) The effects of mercury, copper, and zinc on calcium uptake by larvae of the clam, Mulinia lateralis. Water, Air, Soil Pollut 17:409-414

McLaughlin RE, Dulmage HT, Allis R, Couch TL, Dame DA Hall IM, Rose RI, Versoi PI (1984) U.S. standard bioassay for the potency assessment of Bacillus thuringiensis serotype $\mathrm{H}-14$ against mosquito larvae. Bull Entomol Soc Am 30:26-29

Morrison GE, Petrocelli EA (1991) Suitability of Mulinia lateralis as a euryhaline toxicity test species. 17th Annual

Responsible Subject Editor: A.K. Sparks, Seattle, Washington, USA
Aquatic Toxicity Workshop, Vancouver, BC, Canada, Nov 5-7, 1990. Can Tech Rep Fish Aquat Sci 1774(1-2): $337-340$

Myers P, Yousten A (1978) Toxic activity of Bacillus sphaencus SSII-1 for mosquito larvae. Infect Immun 19:1047-1053

Nestrud LB, Anderson RL (1994) Aquatic safety of Lagenidium giganteum: effects on freshwater fish and invertebrates. J Invertebr Pathol 64:228-233

Osborne LS, Landa Z (1992) Biological control of whiteflies with entomopathogenic fungi. Fla Entomol 75:456-471

Rayburn JR, Fisher WS, Foss SS, Glas PS (1995) Comparison of toxicity test methods using embryos of the grass shrimp, Palaemonetes pugio (Abstract). In: Global environmental protection: science, politics and common sense. Abstract book: Second SETAC World Congress (16th Annual Meeting), 5-9 Nov 1995, Vancouver, BC, Canada. Society of Environmental Toxicology and Chemistry, Pensacola, FL, p 317

SAS Institute Inc (1985) SAS user's guide: Statistics, version 5 edition. SAS Institute Inc, Cary, NC

Singer S, Bair TB, Hammill TB, Berte AM, Correa-Ochoa MM, Stambaugh AD (1994) Fermentation and toxin studies of the molluscicidal strains of Bacillus brevis. J Ind Microbiol 13:112-119

Singer S, Doherty KA, Stambaugh AD (1988) Preliminary examination of molluscicidal strains of the genus Bacillus. 88th Annual Meeting American Society for Microbiology, Miami, FL, May 8-13, 1988. Abstr Annu Meet Am Soc Microbiol 88:76

Manuscript first received: October 4, 1995

Revised version accepted: March 1, 1996 